\title{
DESIGNING PORTAL AMAZING NORTH SULAWESI AS PART OF INDONESIAN E-CULTURAL HERITAGE AND NATURAL HISTORY
}

\author{
Stanley Karouw and Hans Wowor \\ Laboratory of Software Engineering and Information Systems \\ Faculty of Engineering, Sam Ratulangi University, Indonesia \\ Email: stanley.karouw@unsrat.ac.id
}

\begin{abstract}
Digital preservation is one of the ways to make tourism of a nation keeps alive. The tourism of a nation rooted in its culture and nature. The wealth of these tourism spread in many entitites and areas such as cultures and natures. ICT role as key enabler to preserve this cultures and nature tourism. In this paper we proposed a Web Portal following eCultural Heritage and Natural History (eCHNH) Framework. This portal is to increase accessibility, provide availability and comply multi-content for culture and nature tourism of North Sulawesi. We used Agile Unified Process (AUP) Methodology to develop this web portal to emphasize user-oriented and object-oriented development paradigm. This agilecharacteristic would produce web-based applications that meet user expectations and needs.
\end{abstract}

Keywords: AUP, eCHNH, software development

\begin{abstract}
Abstrak
Preservasi digital adalah salah satu cara untuk membuat pariwisata suatu bangsa terus hidup. Pariwisata suatu bangsa yang berakar pada budaya dan alam. Kekayaan pariwisata ini tersebar di berbagai entitas seperti budaya dan alam. Peran ICT sebagai key-enabler untuk melestarikan budaya dan sifat pariwisata. Dalam paper ini kami mem-propose Portal Web eCultural Heritage and Natural History (eCHNH) Framework. Portal ini dibangun untuk meningkatkan aksesibilitas, memberikan availabilitas dan memenuhi multi-konten untuk budaya dan wisata alam Sulawesi Utara. Kami menggunakan metodologi Agile Unified Process (AUP) untuk mengembangkan portal web ini untuk menekankan paradigma berorientasi pengguna dan pengembangan berorientasi objek. Karakteristik agile ini akan menghasilkan aplikasi berbasis web yang memenuhi harapan dan kebutuhan pengguna.
\end{abstract}

Kata kunci: $A U P, e C H N H$, software development

\section{Introduction}

Indonesian researcher, named Hasibuan [1] already proposed a framework called e-Cultural Heritage and Natural History, abbreviated eCHNH based on Zachman's Framework ${ }^{[1]}$. This framework has four major components: Portal, Multichannel Access, Multimedia Information Retrieval and ICT-based Education (see Fig.1)

Portal mentioned as a one stop place to find any eCHNH information from any location in Indonesia. This portal interacts directly with the user and acts as front-end of eCHNH IRS application.

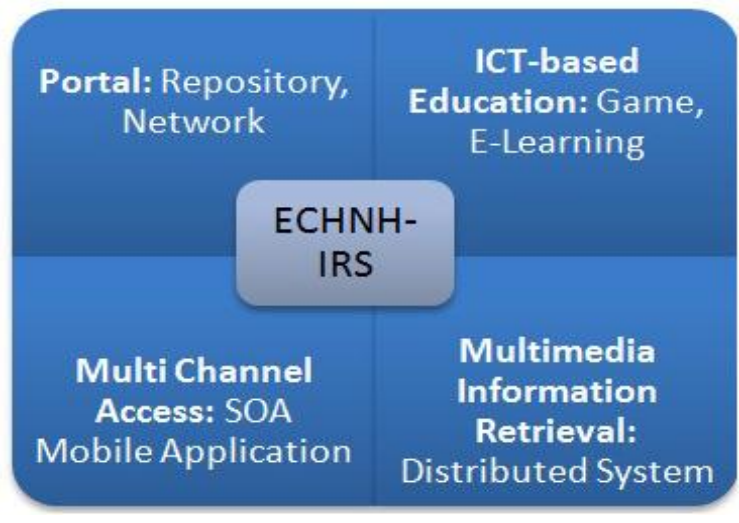

Fig 1. eCHNH Research Areas 


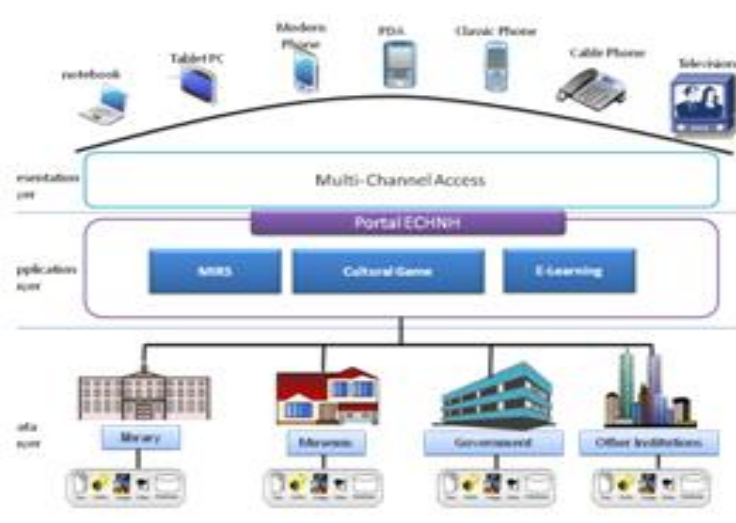

Fig 2. eCHNH Architecture

In the back-end this portal is supported by e$\mathrm{CHNH}$ service engine constructed based on e$\mathrm{CHNH}$ framework. The portal is named eIndonesia (http://e-indonesiana.cs.ui.ac.id) (see Fig.2) [1]. The e-Indonesiana portal ensures all information available can be accessed widely through out with various information technology devices reflected by a wide range of users in Indonesia, from a very traditional user to an advanced user. Users can access e-Indonesiana though computer terminals or mobile devices.

This paper focus is to analyze and design a Web Portal that follows e-CHNH framework. We proposed Portal Web which collect exotic tourism culture and nature from North Sulawesi Region. This Portal also used to promote exotic tourism culture and nature like Bunaken Island. We also realized that lack of comprehensive information about North Sulawesi exotic tourism culture and nature, such like Bunaken Island and various Minahasan Traditional Dancing became one of the reasons for the decline of foreign tourist visiting. Structuring a comprehensive information related to the potential of tourism culture and activities, such as Portal e-Indonesiana became a strategic solution that must be done to fix the pre-eminent tourism promotion. In addition, the information must be displayed in such as interactive user interface, constantly available for $24 / 7$ viewing and able to be found easily. Portal for North Sulawesi Region, called Portal Amazing North Sulawesi expected to be effective solution.

This paper research question is focusing on how to analyze and design an application using agile-based methodology which followed eCHNH framework. We also want to find best practices using agile-based methodology to build webbased application.

\section{Theoritical Considerations}

\subsection{Software Lifecycle Models}

Software lifecycle models, presented by Schach [2] is an ideal software development phases. This model considers the software as a product produced in a specific sequence steps. The specific sequence steps are: 1) Starting from scratch (i.e starting form nothing); 2) Requirements (or needs) definitions; 3) Analysis Phase; 4) Design Stage; 5) Implementation Phase. Sommerville [3] presented four fundamental software lifecycle models stage, which are; 1) Software specification; 2) Software design and implementation; 3) Software validation; 4) Software evolution. Pressman [4] proposed a software generic process framework such as: 1) Communication; 2) Planning; 3) Modelling; 4) Construction; 5) Implementation.

Schach [2] also stated that software lifecycle model contrasted ideally to practical way because of two reasons: 1) software practitioners are humans which tends to make mistakes, 2) users needs and expectation tends to change when the software being developed.

Software Engineering Institute - Carnegie Mellon (SEI) [5] proposed a framework which called CMMI for Development (CMMI - DEV). CMMI® (Capability Maturity Model® Integration) framework is a collection of best practices that help organization to develop software process. This model is developed among industry, government and academia in the SEI. CMMI-DEV, provides a comprehensive set of guidelines related to the development of services and software products.

\subsection{Unified Modelling Language (UML)}

UML stands for Unified Modeling Language, a modeling notations for software applications. Schach [2] confirms that the UML is a language rather than a method. As a language, UML is used to describe software that is developed with a variety of software development paradigm and methodology. Schach opinion [2] is supported by Sommerville [3] and Pressman [4].

Fowler [6] provide a simple definition that UML is a collection of graphical notations, backed by single meta-model, which help descriptions and design of software systems, especially systems that are built using objectoriented programming. UML is an open standard governed by the Object Management Group (OMG), an open consortium. OMG serves to 
create standards that support interoperability of object-oriented systems. The latest version of UML is the UML ver 2.0 [7].

According to Kruchten [8], UML is a graphical language for visualizing, specifying, constructing and documenting any artifacts of software systems. UML supports the $4+1$ View Model of Architecture, i.e 1) The Logical View, 2) The Implementation View, 3) The Process View and 4) The Deployment View plus 5) The Use Case View. Model is a complete representation of a software system, while the architecture is focus of views on certain parts of the system software. Software model and software system architecture connectedness, illustrated by the UML.

\subsection{Agile Unified Process (UML)}

Agile Unified Process (AUP) [11] is one of methodology for software system development using object-oriented paradigm combined with agile practice. AUP Methodology focusing on reused-component. Characteristics of the AUP methodology is intended to consistently adapt to the trend of information systems development, that increasingly large and complex.

Agile approach began to emerge in software development in the era of the 2000s. Principles of agile approaches can be found at Agile Alliance [9]. Jacobson [10] describes agile as a team that is ready to respond to change, the changing needs of users. In this sense means that each development team must closely cooperate with the user in developing web based applications. Response to anticipate the changes are the main characteristics of the agile approach.

AUP stages of problem solving methodology, which proposed by Pusilkom, University of Indonesia [11] refers to Ambysoft Inc. [12] agile approach. (see Fig. 3 and Fig. 4). The phases of analysis and design are as follows:

1. Inception, with the activity of defining project scope, cost estimating and scheduling, define risks, making the feasibility of the project and prepare a project execution environment (team work, installation, and so on). Iteration process is done once. Generated artifacts include Vision, Suplementary Specification document and Software Project Plan which explain Software Estimation and Financial Feasibility Study.

2. Elaboration, with the activity of identifying and validating the application architecture. Iteration process can be done one to two times. The resulting artifacts are Software Requirements Specification (SRS), Software
Architecture Document (SAD) and LCO Inception Phase Update.

3. Construction, with modeling activities, build and test system applications (unit testing) as well as supporting documentation. Iteration process can be done two to eight times. The resulting artifacts are Source Code Document, Test Report, Update SRS and Update SAD.

4. Transition, with activity testing the system (system integration and user testing), review the application and the system, and installation for the working application system. Iteration process can be done one to two times. The resulting artifacts are User Installation Manual and User Manual.

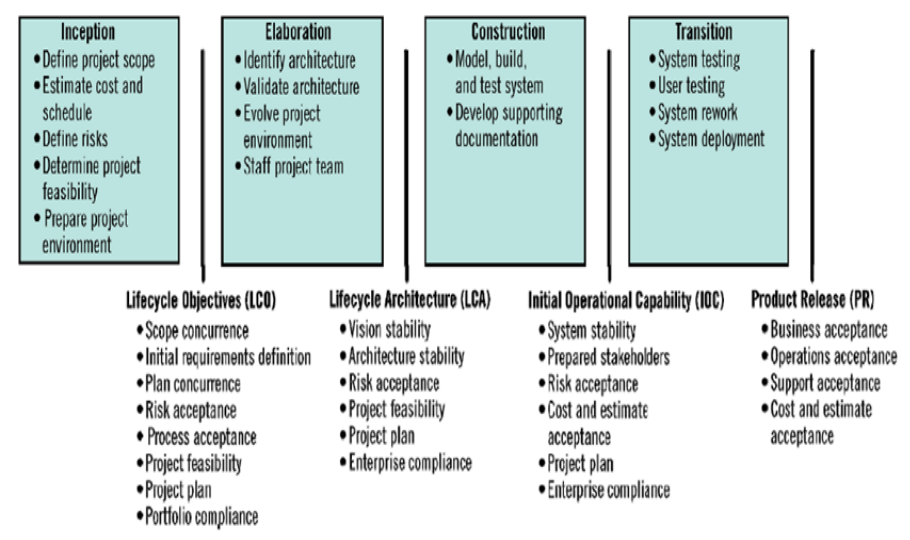

Fig 3. AUP Phases

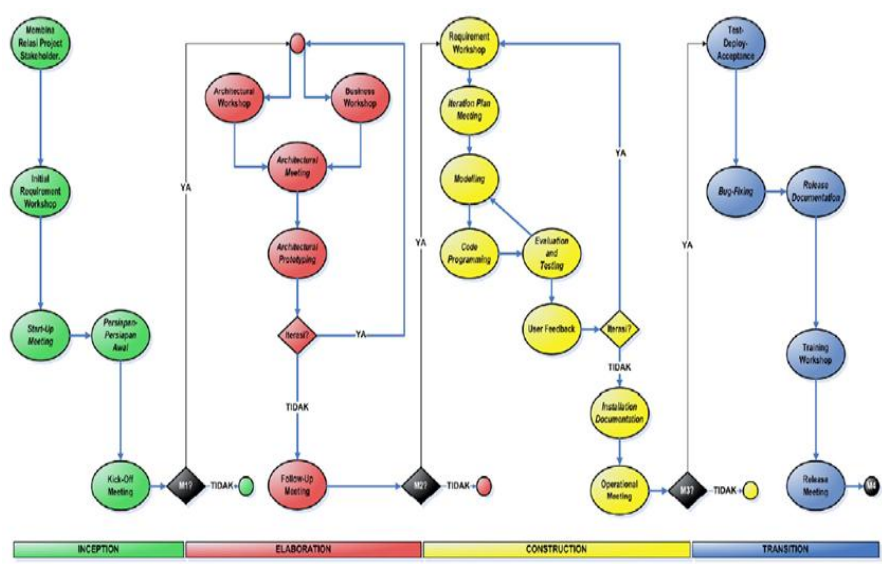

Fig 4. AUP Process Activities

AUP guide from Pusilkom UI also provides LCO (Lifecycle Objective) as final artifacts (documents and presentations) for each phase, as targets to be achieved before proceeding to the next phase. For the purposes of writing this paper, the authors will limit the artifacts to be displayed. 


\section{Analysis and Design}

\subsection{Inception Phase}

\subsubsection{Phase Objectives}

The main target of inception phase is to understand the scope and objectives of the project and obtain enough information to confirm that we must go on or no. Main artifacts which must produced are STRQ, Vision and Software Project Plan document.

\subsubsection{Inception Phase LCO \\ 3.1.2.1. Project Management}

An important part of which is related to Inception phase lifecycle Objectives (LCO) are estimate software size, the number of developers required, working time and costs required. Software size estimation, the number of developers required and working time are counted using Function Point Analysis. While the project cost is calculated by using the ROI, NPV and BEP. Table I summarized this artifacts.

TABLE I

PART OF INCEPTION PHASE ARTIFACTS Software Estimation

\begin{tabular}{ll}
\multicolumn{2}{c}{ Software Estimation } \\
\hline Total Adjusted Function Point & 152.29 \\
Lines of Code (LOC) & 67000 \\
Effort (in person-months) & 11.71 \\
Estimate Time Required & 7 months \\
Net Present Value (NPV) & Rp. 5.901.567,- \\
Return on Investment (ROI) & $52.24 \%$ in 2 months \\
Break Event Point (BEP) & 2.34 months \\
\hline
\end{tabular}

\subsubsection{Main Functionality}

Application main functionality are classified into functional requirements and non-functional requirements. The focus for application development lies at functional requirements. Interviews and Questionering are technique for gathering the user requirements. We also developed User Stories to collect user requirements. Functional requirements are collected from stakeholders such as project champion, users and developer team. Table II below listed all main functionalities.

\subsection{Elaboration Phase}

\subsubsection{Phase Objectives}

Elaboration is the second phase in the software development lifecycle. The target of this phase is to determine the base architecture of the system. This base system architecture will guide construction and implementation phase activities.

\subsubsection{Elaboration Phase LCO}

LCO artifacts which mainly related to the elaboration phase are summarized in the SRS document and SAD document. Mostly, artifacts provides archtiecture model for the whole software system.

\subsubsection{Functional View}

We used UML Use Case Diagram and UML Use Case Description as functional requirements model. However, the complete list of UML Use Case Description are not presented in this paper. Fig. 6 depicted UML Use Case Diagram as Functional View Model. One of the UML Use Case Description can be read at Table III below.

\subsubsection{Logical View}

The static structure model (also called Logical View) of system application describes all the classes and relationships between classes in the system application. This view also depicted the design of data management including data access logic manipulation layer and its actual design of the storage. ERD Diagram (see Fig. 7) describe the static structure model of system application.

TABLE II

MAIN FUNCTIONALITY

\begin{tabular}{|c|c|}
\hline \multicolumn{2}{|c|}{ Functional Requirements } \\
\hline 1. Viewing Info & $\begin{array}{l}\text { 1.1 The system can display information about the } \\
\text { ads, profile, headline news, cultural articles, } \\
\text { cultural games, cultural info, testimony and search } \\
\text { result } \\
\text { 1.2 The system can display links } \\
\text { 1.3 The system can display visitor counter for each } \\
\text { pages } \\
\text { 1.4 The system can display currency value and } \\
\text { weather report }\end{array}$ \\
\hline 2. Managing Info & $\begin{array}{l}\text { 2.1 Input ads, profile, news, headline and articles } \\
\text { 2.2 Edit ads, profile, news, headline and articles } \\
\text { 2.3 Delete ads, profile, news, headline and articles } \\
\text { 2.4 Save ads, profile, news, headline and articles }\end{array}$ \\
\hline $\begin{array}{l}\text { 3. Collaborating } \\
\text { Data }\end{array}$ & $\begin{array}{l}\text { 3.1 The system must provide facilities for posting } \\
\text { and reply comments for news, headline and articles } \\
\text { 3.2 The system must provide sharing features for } \\
\text { social media, i.e: Facebook, Twitter and G+ } \\
\text { 3.3 The system musti provide polling feature }\end{array}$ \\
\hline \multicolumn{2}{|c|}{ Non Functional Requirements } \\
\hline $\begin{array}{l}\text { 1. Operational } \\
\text { Requirement }\end{array}$ & $\begin{array}{l}\text { 1.1 The system must be displayed in Indonesian } \\
\text { and English; } \\
\text { 1.2 The system can be operated on a smartphone, } \\
\text { desktop and notebook on the optimal display } \\
\text { resolution; } \\
\text { 1.3 The system must be able to work on all web } \\
\text { browsers } \\
\text { 1.4 The System must running through the operating } \\
\text { system Windows and Linux }\end{array}$ \\
\hline $\begin{array}{l}\text { 2. Performance } \\
\text { Requirements }\end{array}$ & $\begin{array}{l}2.1 \text { The system must be used or operated within } 24 \\
\text { hours a day, } 7 \text { days a week and } 356 \text { days a year } \\
2.2 \text { Each user interaction with the system should } \\
\text { not be longer than } 3 \text { seconds }\end{array}$ \\
\hline $\begin{array}{l}\text { 3. Security } \\
\text { Performance }\end{array}$ & $\begin{array}{l}\text { 3.1 The system must provide privilege access for } \\
\text { groups of admins and users } \\
3.2 \text { The system must provide verification procedure } \\
\text { for posting comments }\end{array}$ \\
\hline
\end{tabular}

1.1 The system can display information about the , profile, headline news, cultural articles, result

1.2 The system can display links

1.3 The system can display visitor counter for each weather repo

2 Edit ads, profile, news, 3.1 The system must provide facilities for posting reply comments for news, headline and articles .2 The system must provide sharing features for

1.1 The system must be displayed in Indonesian and English; resolution; system Windows and Linux hours a day, 7 days a week and 356 days a year not be longer than 3 second

groups of admins and users for posting comment 


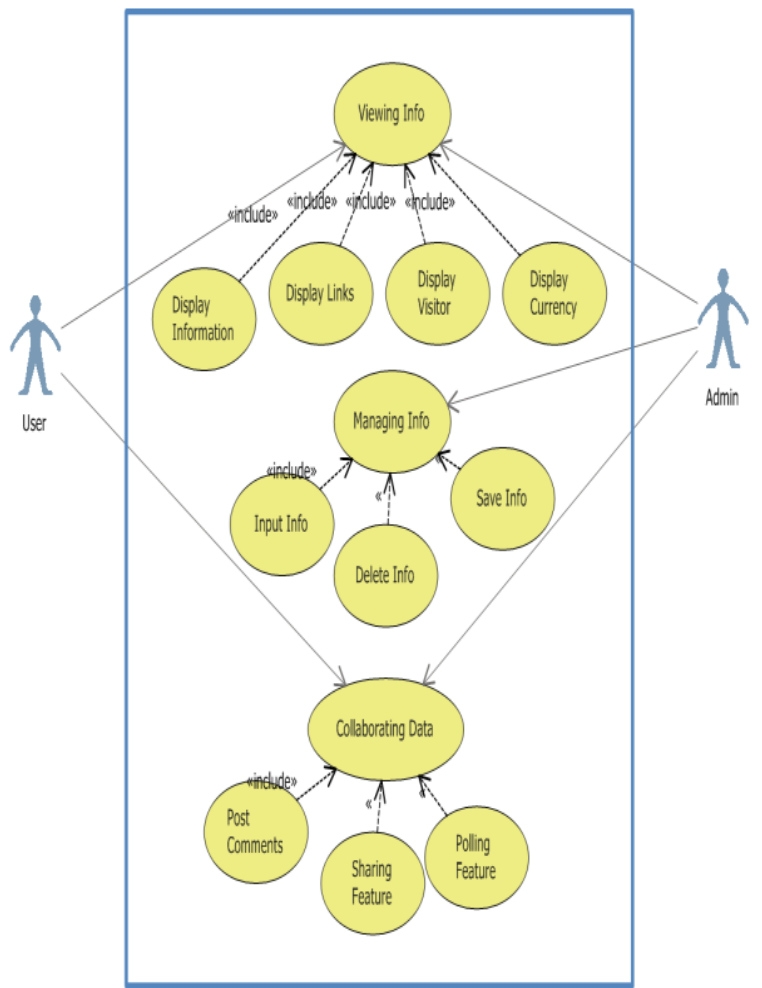

Fig. 5. UML Use Case Diagram

TABLE III

USE CASE DESCRIPTION: DISPLAY INFORMATION SEARCH

\begin{tabular}{|c|c|c|}
\hline Use Case Name & \multicolumn{2}{|c|}{ Display Info Searching } \\
\hline Actor: & \\
\hline Description: & \multicolumn{2}{|c|}{$\begin{array}{l}\text { User input keyword then system validate } \\
\text { keyworad and display search result }\end{array}$} \\
\hline & User & System \\
\hline & $\begin{array}{l}\text { 2. Type } \\
\text { keyword }\end{array}$ & 1. Show form search \\
\hline Normal Course: & $\begin{array}{l}\text { 5. Click search } \\
\text { result }\end{array}$ & $\begin{array}{l}\text { 3. Validate keyword } \\
\text { 4. a Search found, } \\
\text { display search result } \\
\text { 6. Display search } \\
\text { detail }\end{array}$ \\
\hline $\begin{array}{l}\text { Alternate } \\
\text { Course: }\end{array}$ & & $\begin{array}{l}\text { 4b. search not } \\
\text { found, show Error } \\
\text { Mesage }\end{array}$ \\
\hline $\begin{array}{l}\text { Pre-condition } \\
\text { Post-condition } \\
\text { Assumption }\end{array}$ & \multicolumn{2}{|l|}{$\begin{array}{l}\text { Login } \\
\text { Logout }\end{array}$} \\
\hline
\end{tabular}

\subsubsection{Implementation View}

To describe implementation view, we used UML Navigation Diagram. Fig. 7 and Fig. 8 describe the implementation view for admins and users.

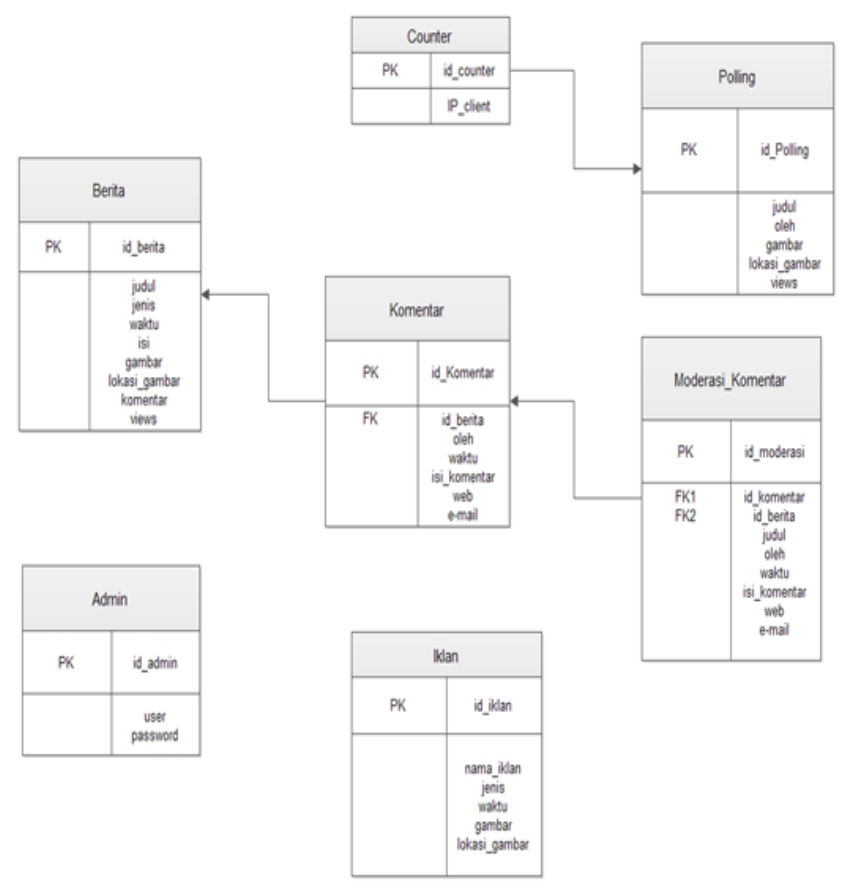

Fig 6. ERD Diagram Model

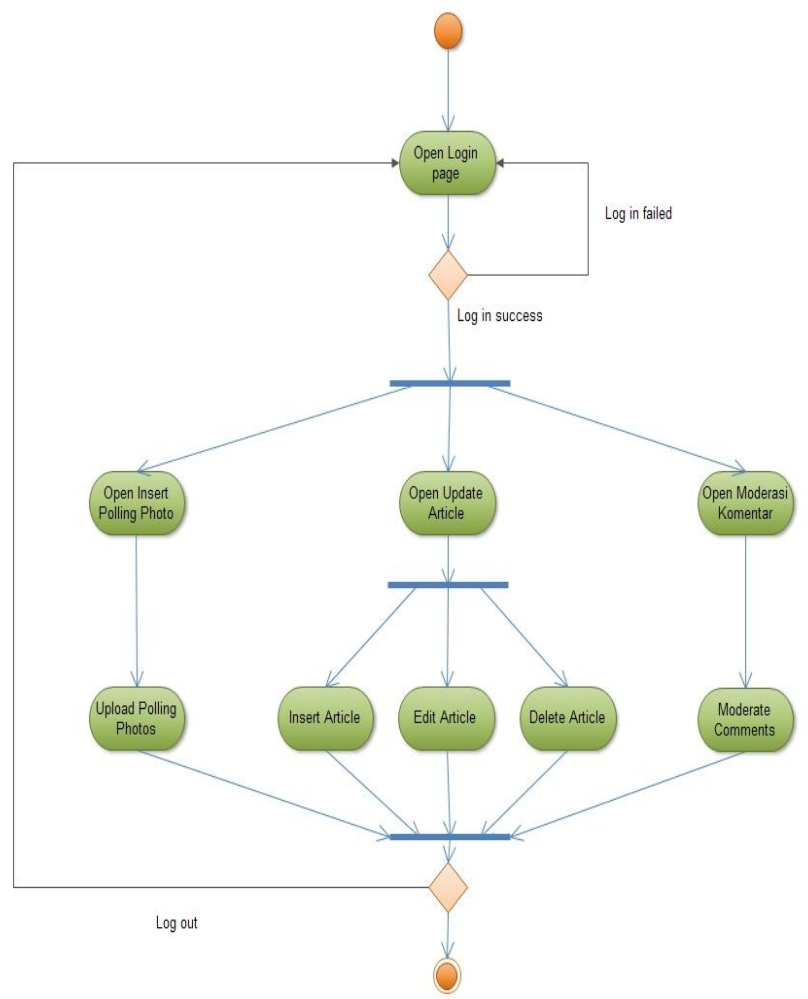

Fig 7. UML Navigation Diagram for Admin 


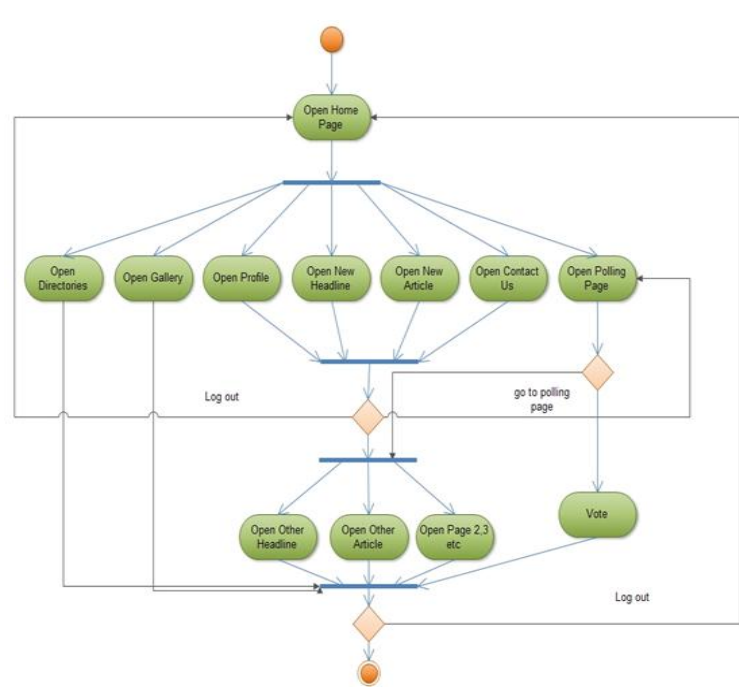

Fig 8. UML Navigation Diagram for User

\subsubsection{Process View}

Process view used to describe the system application behaviour. This software process model is to provide an overview of the behavior of existing objects in the application. We have used UML Sequence Diagram to explain behaviour system application. (see Fig. 9)

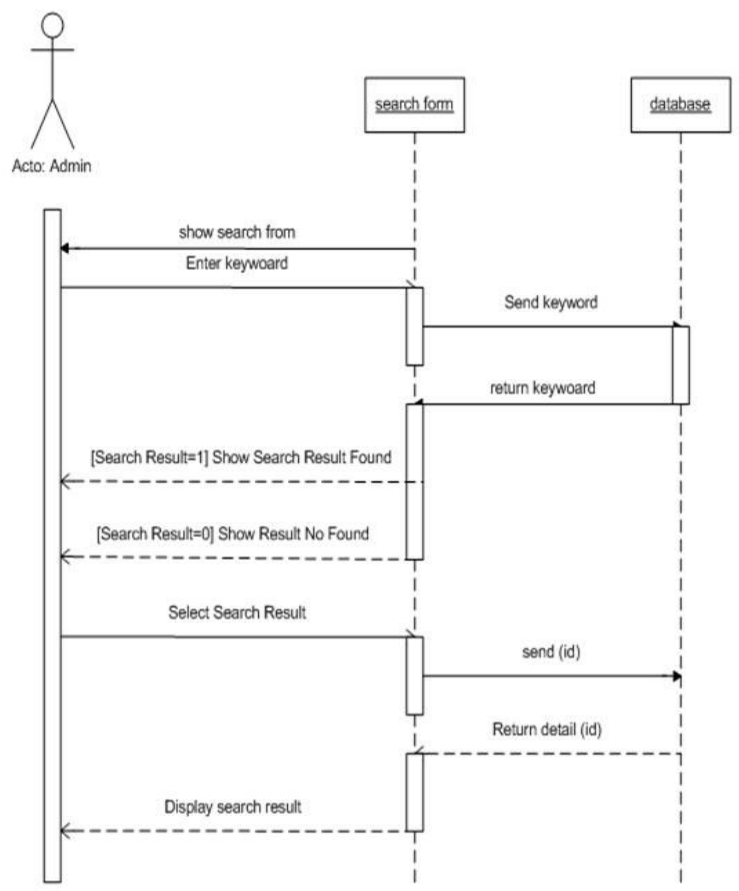

Fig 9. UML Sequence Diagram for Searching

\subsubsection{Interface Design Layer}

Interface design is the process of defining how the system interacts with an external unit. The user interface consists of 3 (three) basic parts. The first is the navigation mechanism, a way of giving instructions to the user and the system tells the system what to do, such as buttons and menus. The second is the input mechanism, a way of capturing information system (e.g a form to add news). The third is the output mechanism of how the system provides information to users or to other systems (e.g reports, web pages). (see Fig. 10).

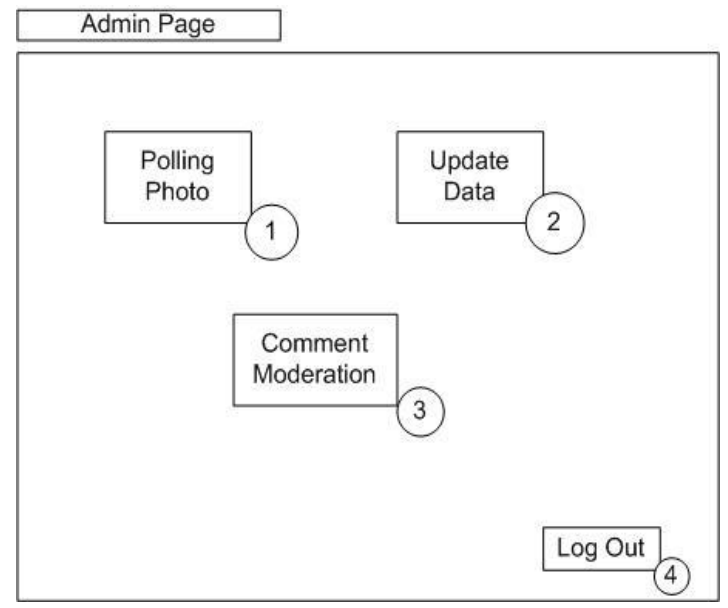

Fig 10. Admin Page Storyboard

\subsection{Construction Phase}

Codification process using xHTML, CSS and JavaScript. The coding applications snapshot can be seen in Fig. 11 below

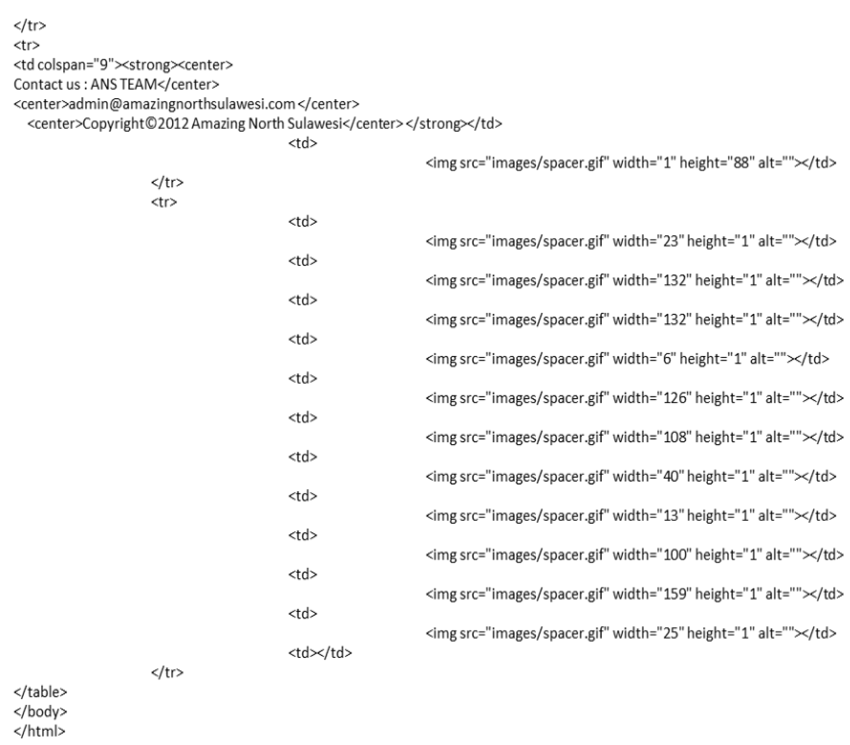

Fig 11. Coding Snapshot

\subsection{Transition Phase}

Physical layer design Architecture applications developed using the client-Server achitecture to maintain a balance between client and server processes which have the function of each application. Client is responsible for the 
presentation logic while the server is responsible for application logic, the data access logic (RDBMS) and data storage. However, this DBMS must comply with eCHNH Framework for Multimedia Information Retrivel (see Fig. 12) [1].

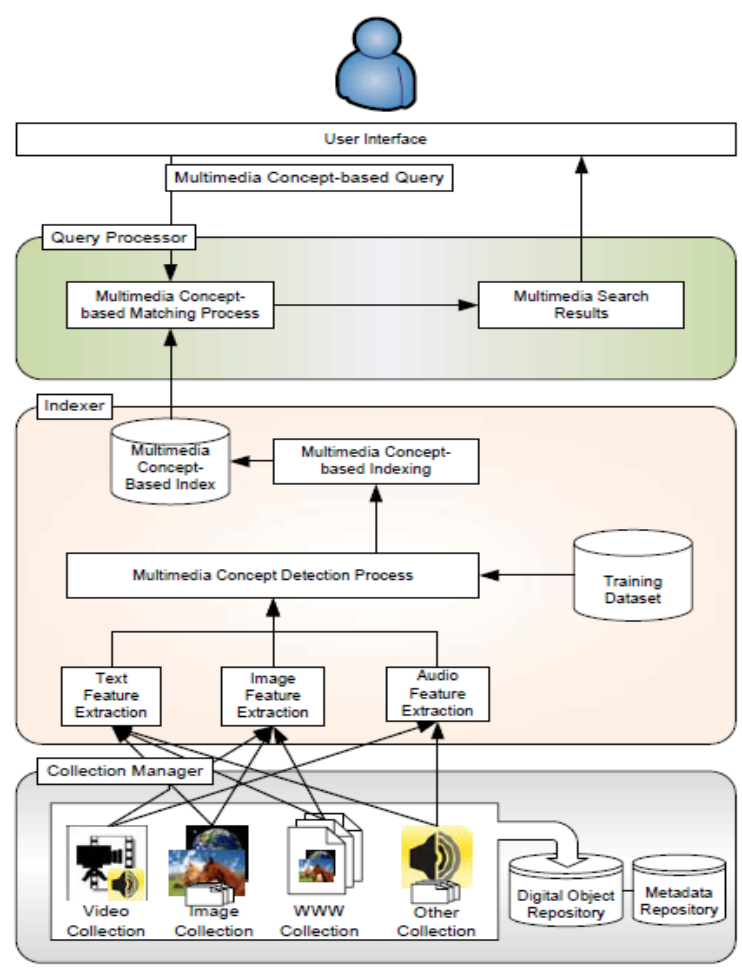

Fig 12. Multimedia IR from eCHNH Framework [1]

\section{Conclusion}

This paper show the analysis and design process to develop regional-level applications which follow eCHNH framework. Portal, as part of eCHNH component must be developed earlier to provide data repository. Portal also can be used to promote North Sulawesi tourism ${ }^{[13]}$, as part of Indonesian cultural heritage. Some conclusions from the writing of this paper include:

1. eCHNH Framework can be used as architecture platform to design regional cultural heritage and natural history applications. Each component from this framework must be implemented one-by-one begin with collecting data by building regional portal.

2. Agile Unified Process Methodology, which is abbreviated AUP, can be used to build Web-based applications with object-oriented approach. Main characteristic of this AUP Methodology is stakeholder active involvement.

3. UML version 2.0 can be used as tools for making software model in detail and simple, so it is very useful for developers and users.
When used in the AUP Methodology, precision is required in selecting of UML diagrams appropriate for developers and easily understood by the user; to the effectiveness of each process related with analysis and design process. In practical terms, UML can be represented in the form of sketches.

4. Development of Web-based applications using the agile-based methodology have higher relative risk of scope creep. It takes a careful risk control process by the developer and stakeholders.

5. Portal Amazing North Sulawesi also can be a reasonable solution to foster North Sulawesi Province tourism investment.

\section{References}

[1] Hasibuan., Zainal, An Overview of Integrated Approach to Digital Preservation: Case Study of Indonesia E-Cultural Heritage and Natural History Information Retrieval System, Invited Paper ICACSIS 2011, ISBN: 979-979-1421-11-9, 2011

[2] Schach., Object Oriented Software Engineering, $8^{\text {th }}$ Ed, McGrawHill, 2008.

[3] Sommerville., Software Engineering, $8^{\text {th }}$ ed, Pearson Education Limited, 2007

[4] Pressman, Software Engineering, A Practitioner's Approach, $6^{\text {th }}$ ed, McGrawHill, Singapura, 2005.

[5] CMMI Product Team, CMMI® for Development, Version 1.3, Improving processes for developing better products and services, November 2010, TECHNICAL REPORT CMU/SEI-2010-TR-033 ，ESCTR-2010-033, Software Engineering Process Management Program, Unlimited distribution subject to the copyright.

[6] Martin Fowler, UML Distilled, A Brief Guide to the Standard Object Modelling Language, $3^{\text {th }}$ ed, Pearson Education, 2004.

[7] Unified Modelling Language: Superstructure Version 2.0, www.uml.org (accesed at Monday, May $13^{\text {th }} 2013$ )

[8] Philippe Kruchten, The Rational Unified Process An Introduction, $3^{\text {rd }}$ ed, Pearson Education, 2004.

[9] Agile Alliance Official Website http://www.agilealliance.org/ (accessed at Monday, May $13^{\text {th }} 2013$ )

[10] Jacobson, I., A Reasoning 'Yes' to Agile Processes - But Also More," Cutter IT Journal, vol 15, no.1, January 2002, pp. 1824

[11] http://ecl.cs.ui.ac.id/PAUS/index.htm (accessed at Monday, May $13^{\text {th }} 2013$ ) 
[12] http://www.ambysoft.com/ (accessed at Monday, May $13^{\text {th }} 2013$ )

[13] Kurniawan., Heri, Salim., Agus., Suhartanto, Heru., Hasibuan, Zainal., e-Cultural Heritage and Natural History Framework:
An Integrated Aproach to Digital Preservation, Proceedings of International Conference on Telecommunication Technology and Applications 2011, vol 5, IACSIT Press, Singapore 